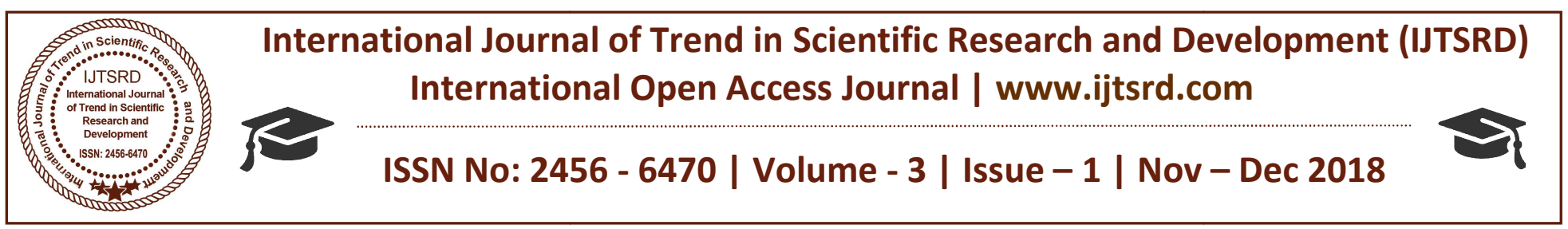

\title{
Demographic Development Tendencies of the Family in Uzbekistan
}

\author{
Abduramanov Hamid Khudaybergenovich \\ Professor, Tashkent State University of Economics, \\ Tashkent, Uzbekistan
}

\begin{abstract}
This article demonstrates that the socio-economic reforms in Uzbekistan that meet the growing demand and effectiveness of the family are important factors in the family and its role as a component of the family and its development. Also, the demographic factors such as the birth and birth of the child and their divergence directly influence the organization and regularity of the family and its statistical indicators are analyzed on the scientific basis.
\end{abstract}

KEY WORDS: Family, family demographic, demographic factors, marriage, divorce, age and gender structure of the population.

\section{INTRODUCTION}

The family plays a crucial role in responding to the needs of modern socio-economic reforms in Uzbekistan. Because family is a component/ of society, which has a great influence on its development (X. Mamadalieva, 2017).

The global development of the family in Uzbekistan is viewed globally within the United Nations Sustainable Development Goals as well as in the five strategically important directions of the development of the Republic of Uzbekistan for 2017-2021 (Decree of the President of the Republic of Uzbekistan of June 27, 2018, 3808). Family development and the establishment of a number of social, economic and demographic factors associated with it. Among these demographic factors - marriage, birth and divorce directly influence the organization and regularity of the family.

Marriage, birth of children, and divorce are interrelated processes in a person's family life. The Family begins with marriage. The basis of its creation is marriage. While the proportion of young people in the country (province, district) is high, it is the main demographic base for the creation of new families in this area. Therefore, to identifying the demographic development of the family requires, the firstly, the marriage, divorce and birth out of the marriage without a deep study of the process requires an associated integral.

\section{Analysis and discussion}

Establishment of the family and its quantitative of fluctuations depend primarily on the demographic status of society. The demographic situation is characterized by such the processes as the age and gender structure of the population, marriages, divorce, birth, death, and migration (M. Buriyeva, 1997).

The age and gender structure of the population are of particular importance when forming a family. If there is a high proportion of young people aged 20-29, it will result in the emergence of new families and the increase in the number of families. According to the Statistics Committee, the number of permanent population aged 20-29 years increased from 6142.9 thousand in 2012 to 6280.8 thousand in 2017 or by $2.2 \%$ in the last six years (www.gender.stat.uz). In this period, the number of young people between the ages of 20 and 29 in the Republic of Karakalpakstan (5.3\%), Bukhara $(0.3 \%)$, Navoi $(0.5 \%)$, Syrdarya $(3.0 \%)$, Tashkent regions (at 3.4\%), Tashkent city $(10.2 \%)$.

But the analysis on the years that we have, starting from the year 2015 in all regions of Uzbekistan in the age of its permanent population and the decrease in the number of 20-29 the start (in 2017 than in 2015 their number in the republic to $1 \%$, while it decreased to 0.7 percent of than 2016). In 2012, the proportion of people aged 20-29 in the permanent population was 20.4 percent and in 2017 it was 19.2 percent. 
According to the forecast, it is expected that in 2030 the population will be reduced by $24-29$ and $30-34$ years. This situation is also characterized by a decline in the number of families due to the decline in the number of young people living in the near future.
Regular continuation of the family, its rebuilding, is primarily dependent on the family's demographic activity (Abdurakhmonov $Q$ and etc, 2014).

Table 1. Starting from 2015, the number of births in Uzbekistan has declined

\begin{tabular}{|c|c|c|c|c|c|c|c|c|}
\hline & \multicolumn{3}{|c|}{ Years } & \multicolumn{2}{|c|}{ Change in births, $\%$} & \multicolumn{3}{|c|}{$\begin{array}{c}\text { The number of } \\
\text { births per } 1,000 \\
\text { people }\end{array}$} \\
\hline & 2015 & 2016 & 2017 & $\begin{array}{c}\text { In } 2017 \\
\text { compared } \\
\text { to } 2016\end{array}$ & $\begin{array}{c}\text { In } 2017 \\
\text { compared } \\
\text { to } 2015\end{array}$ & $2015 y$ & $2017 y$ & $\begin{array}{r}2017 \\
2015\end{array}$ \\
\hline The Republic of Uzbekistan & 734141 & 726170 & 715519 & $-1,5$ & $-2,5$ & 23,5 & 22,1 & $-1,4$ \\
\hline $\begin{array}{l}\text { The Republic of } \\
\text { Karakalpakstan }\end{array}$ & 41345 & 39427 & 37754 & 42 & $-8,7$ & 23,3 & 20,6 & $-2,7$ \\
\hline Regions: & & & & & & & & \\
\hline Andijan & 69562 & 68784 & 67368 & $(4 / /-2,1$ & $-3,2$ & 24,1 & 22,6 & $-1,5$ \\
\hline Bukhara & 39352 & 38297 & 37228 & $-2,8$ & $-5,4$ & 21,9 & 20,0 & $-1,9$ \\
\hline Jizzakh & 31887 & 31566 & 30984 & $-1,8$ & $-2,8$ & 25,2 & 23,6 & $-1,6$ \\
\hline Kashkadarya & 78543 & 77684 & 76687 & $-1,3$ & $-2,4$ & 26,2 & 24,6 & $-1,6$ \\
\hline Navoi & 20259 & 20837 & 20563 & $-1,3$ & $+1,5$ & 22,0 & 21,6 & $-0,4$ \\
\hline Namangan & 61980 & 62164 & 61380 & $-1,3$ & $-1,0$ & 24,0 & 22,9 & $-1,1$ \\
\hline Samarkand & 88649 & 88295 & 89956 & $J+1,9 \cap$ & $+1,5$ & 25,0 & 24,4 & $-0,6$ \\
\hline Surkhandarya & 64424 & 62638 & 64908 & $+3,6$ & $+0,8$ & 27,0 & 26,1 & $-0,9$ \\
\hline Syrdarya & 17862 & 17623 & 17627 & 0,0 & $-1,3$ & 22,8 & 21,8 & $-1,0$ \\
\hline Tashkent & 58692 & 57190 & 54794 & $-4,2$ & $-6,6$ & 21,1 & 19,3 & $-1,8$ \\
\hline Fergana & 79241 & 78587 & 75501 & $-3,9$ & $-4,7$ & 22,8 & 21,0 & $-1,8$ \\
\hline Khorazm & 39543 & 39199 & 37619 & $n e-4,0$ & $-4,9$ & 22,8 & 21,0 & $-1,8$ \\
\hline Tashkent c & 42802 & 43879 & 43150 & $-1,7$ & 0,8 & 18,0 & 17,7 & $-0,3$ \\
\hline
\end{tabular}

Source: Based on the compose of the State Statistics Committee of the Republic of Uzbekistan

As can be seen in the first table above, the number of births in 2017 decreased by 2.5 percent compared to 2015 and 1.5 percent compared to 2016. Absolute number of births in all regions except for Samarkand and Surkhandarya regions decreased. The number of births per 1,000 population decreased in all regions of the country. The lowest birth rates were observed in the city of Tashkent (17.7\%), Tashkent region $(19.3 \%)$, Bukhara region $(20 \%)$ and the Republic of Karakalpakstan (20.6\%o).

The decline in birth rates in the country is due to the following factors: planning of the number of children for each family based on their economic potential (1-2 in urban areas and 2-3 children in rural areas); prolongation of marriage age (26.3 years for males in 2017 and 22.8 years for women at www.gender.stat.uz), changing the health of the population by means of the prolonging the periodicity of reproductive health, favorable age for the women - stimulation of childbearing at the age of 20-30, significantly expanding access to contraception, including free-of-charge, of the population. Widespread use of contraceptives to prevent unwanted pregnancy; Changing reproductive views of women on low birth rates due to the increased financial responsibility of families for children. It also depends on women's important role in the formation of financial resources of the family budget; external labor migration of the population; the impact of ongoing global trends in birth rates.

The Mortality rates directly affect the demographic development of the family. Because only a part of the birth of the natives is left in the family. The number of deaths in Uzbekistan in 2013 was 145,600, in 2017 was 160,700 (www.stat.uz) or by $10.3 \%$ in the past five years. In this period, the death rate of men increased by $11.3 \%$, and the death rate of women - by $9.2 \%$. The highest death rate in the republic is 
observed in the city of Tashkent (6.7\%), Tashkent $(5.7 \%)$ and Andijan $(5.3 \%)$. The mortality rate determines the expected life expectancy at birth.

According to the State Statistics Committee of Uzbekistan, the expected life expectancy in the country over the last five years (2013-2017) was 73.7 years, reaching 73.7 years. The highest degree of the life expectancy (2017) in Jizzakh region (75.7 years), Bukhara region (75.5 years) and Tashkent city (74.5 years) are the lowest in Syrdarya region 70.6 years).

In many respects, their low survival rates remain high due to a high proportion of men age-related deaths. The great difference in length of life of men and women leads to a significant change in the gender composition of the population. The highest number of women is registered in all age groups aged 35-40 years (Q.Abdurahmonov, X.Abduramanov, 2011). This has the following effect on the demographic development of the family:

1. In the family, the father's children are born, and their maternal deaths (labor-age age) are the only part of their mother's care and education. So, financial support is provided to the mother. Because of the fact that these children have higher education in the family (higher education institutions are basically contract-based), they are deprived of higher education and are forced to work (especially in other paid countries). It is therefore desirable to simplify the mechanism for issuing educational loans to the families (city, (district), and families).

2. The death of men in the family necessitates the aggravation of social problems, the development of measures aimed at improving the health of the population, and the need for gender mainstreaming in the provision of social services for elderly people.

Such a large difference in the duration of life among men and women necessitates prolongation of men's lifetime. This is a major contributor to the further growth of life expectancy in Uzbekistan. Implementing this task will allow prolonging the lives of hundreds of thousands of working adults.

There are women's counseling and maternity hospitals in the country, which performs useful activities among of women. Additionally, it is important for men to provide counseling services for men to help increase the lifetime of men. It was time for the protection of motherhood and the protection of the fatherhood. It should be noted that the low level of life of men is the problem of the country and the economy because, in some countries, the shortage of men's labor force is the result of the premature death of male-capable males.

Marriage is one of the factors directly affecting the demographic development of the family, which is a form of male and female historically composed, interconnected, and relationships to the children.

The majority of marriages in the country are married at the age of 20-29. During the last five years (20132017), the number of marriages in the age group of $16-19,20-24$ has sharply decreased. The number of married men aged $25-29$ increased by $7.9 \%$ and the number of married women increased by $4.1 \% .85 \%$ of the population is married at age $20-29$. It turns out that the number of those aged 20-24 years old has diminished and the rate of growth of 25-29 years has dropped dramatically over other age groups. 40-44, 45-49, 50-54, 55-59, 60 years and older adult males. In particular, the number of married people in the age group of $55-59$ years increased by $78.5 \%$ and $61.7 \%$ respectively.

According to the State Statistics Committee of Uzbekistan, the number of divorces in the country is increasing every year. If in 2013 the number of divorces was 24025 , it was 31929 , or $32.9 \%$ more than in 5 years. It is sad that the number of divorces has increased in all parts of the country except for Tashkent. However, the declining factor in Tashkent is the highest ( 1.5 per 1000 people). Such high indicators are also observed in the Sirdarya (1.4), Tashkent (1.3) and Navoi (1.2) provinces.

In recent years, the family has been a major cause of chronic alcoholization (N. Yuldashev, 2017), a lack of understanding of each other in the family, lack of harmony, childhood, intercourse with other people's personal lives. In addition, the increase in the number of divorces has been accompanied by an increase in the national composition of the region's population (Russians, Ukrainians, Tatars, Koreans and other European peoples), increasing the level of education of the population (especially women), increased labor migration and the low level of demographic literacy of parents level etc. It is important to conduct a 
special study on this subject, in-depth study of the key factors.

\section{Conclusions and suggestions}

It is time to develop and approve the program of realization of the concept of state demographic policy in Uzbekistan. The goal of this program is to create the conditions for the emergence of smart demographic development and improving the quality of life of the population. The main focus of the program is to raise awareness of the population about the cultural-educational level, care for health, care for health, and the role of women in society.

It should be noted that the birth control arrangements in Uzbekistan should include: improving the quality of the population; increasing the activity of women in obtaining general and vocational education; population employment and urbanization development; increasing the level and quality of life of citizens in the republic; strengthening the government's influence on the family, the working team, the individual's behavior; family and marriage, etc. It is expedient to allocate funds from the state budget as well as the UN Population Fund, the United Nations Development Fund for Women (UNIFEM) and other international financial institutions to implement the Concept of Demographic Policy.

In order to effectively implement the measures to strengthen the marriage and family relations, it is necessary to create jobs that have a favorable and well-paid job, which will lead to the collapse of fights that may arise in the family, both economically and spiritually. Establishing a long-term government program for the strengthening of marriage and family, raising the responsibility of the husband and wife to families and children, establishing counseling services for the marrying couples in order to explain the divorce itself, their children and the general public, organization of short-term courses on family relations, introduction of demography course in higher education institutions and secondary schools, and marriages of young people us to organize lectures and seminars in the field of marriage, family and the media are engaged in scientific research institutions need to strengthen the relationship with the government.

\section{References}

1. Abdurakhmonov Q., Abduramanov X. X. (2011). Demography. Educational manual. - T.: Publisher, p. 296.

2. Abdurakhmonov Q. X. and others. 2014. Demography. Textbook. - T.: "ECONOMIC", p.364.

3. Buriyeva M. R. 1997. Family Demography in Uzbekistan. Monograph. - Tashkent: University.

4. Mamadalieva X. 2017. Social and demographic development of the family in Uzbekistan. Monograph. - Tashkent: Global books. p.3.

5. Yuldashev N. N. (2017). Changes in demographic processes affecting the institution of the family in Uzbekistan // The Scientific Electronic Journal of "Economics and Innovative Technologies”. № 4.

6. www.lex.uz. (2018). Decree of the President of the Republic of Uzbekistan № 3808 “On Approval of the Concept of Strengthening the Institution of Family in the Republic of Uzbekistan" of June 27, 2018.

7. www.gender.stat.uz.

8. www.stat.uz. 